\title{
Effect of Crocus sativus L. Stigmas Microwave Dehydration on Picrocrocin, Safranal and Crocetin Esters
}

\author{
Aarón García-Blázquez ${ }^{\dagger}$, Natalia Moratalla-López ${ }^{\dagger}$ (D) , Cándida Lorenzo, M. Rosario Salinas (D) \\ and Gonzalo L. Alonso *(i)
}

check for

updates

Citation: García-Blázquez, A.;

Moratalla-López, N.; Lorenzo, C.;

Salinas, M.R.; Alonso, G.L. Effect of

Crocus satious L. Stigmas Microwave Dehydration on Picrocrocin, Safranal and Crocetin Esters. Foods 2021, 10, 404. https://doi.org/10.3390/ foods10020404

Academic Editor: Sidonia Martinez and Javier Carballo

Received: 25 January 2021

Accepted: 8 February 2021

Published: 12 February 2021

Publisher's Note: MDPI stays neutral with regard to jurisdictional claims in published maps and institutional affiliations.

Copyright: (c) 2021 by the authors. Licensee MDPI, Basel, Switzerland. This article is an open access article distributed under the terms and conditions of the Creative Commons Attribution (CC BY) license (https:// creativecommons.org/licenses/by/ $4.0 /)$
Cátedra de Química Agrícola, E.T.S.I. Agrónomos y Montes, Universidad de Castilla-La Mancha, Campus Universitario, 02071 Albacete, Spain; Aaron.Garcia@uclm.es (A.G.-B.);

Natalia.Moratalla@uclm.es (N.M.-L.); Candida.Lorenzo@uclm.es (C.L.); Rosario.Salinas@uclm.es (M.R.S.)

* Correspondence: Gonzalo.Alonso@uclm.es; Tel.: +34-967-59-92-10; Fax: +34-967-59-92-38

+ Both authors contributed equally to this work.

Abstract: The dehydration process is the basis to obtain high quality saffron and to preserve it for a long time. This process modifies saffron's main metabolites that define its quality, and are responsible for the characteristic color, taste, and aroma of the spice. In this work, the effect of microwave dehydration on saffron main metabolites (picrocrocin, safranal and crocetin esters) from Crocus sativus L. stigmas at three determinate powers and different time lapses was evaluated. The results showed that this dehydration process obtained similar or lower crocetin esters content, and after three months of storage, higher concentration was shown in treatments at $440 \mathrm{~W}$ for $36 \mathrm{~s}, 55 \mathrm{~s}$, and $73 \mathrm{~s}$; at $616 \mathrm{~W}$ for $90 \mathrm{~s}$; and at $800 \mathrm{~W}$ for $20 \mathrm{~s}$. Picrocrocin content was lower and safranal content was higher in all treatments compared to the control both before and after storage. Regarding to commercial quality, microwave dehydration obtained Category I of saffron according to International Standard Organization (ISO) 3632. After three months of storage, treatments at $616 \mathrm{~W}$ for $83 \mathrm{~s}$ and $800 \mathrm{~W}$ for $60 \mathrm{~s}$ obtained lower categories. The results obtained suggest that microwave dehydration is a suitable process for obtaining high quality saffron, $800 \mathrm{~W}$ with 6 lapses of $20 \mathrm{~s}$ being the best conditions studied.

Keywords: saffron quality; secondary metabolites; drying; high performance liquid chromatographydiode array detection (HPLC-DAD); spectrophotometry

\section{Introduction}

Saffron is the dried stigmas of Crocus sativus L. and its high value is due to its colour, flavour, and aroma [1]. There is confusion about the names of the spice and the plant. C. satious L. is the plant, while saffron refers to the spice obtained from the dehydrated stigmas of the plant itself $[2,3]$. Therefore, the dehydration process is necessary to convert C. sativus L. stigmas into saffron.

Traditionally, saffron in Spain is obtained by C. sativus L. stigmas dried by a process called "toasting", in which stigmas are put on a sieve with a silk bottom placed over a heating source, whereas in other countries, in terms of temperature, stigmas are dehydrated at room temperature under sunlight or in the shade. Stigmas' dehydration is the key process to obtaining the spice and is responsible for saffron composition [4-6]. During this process, stigmas lose around $80 \%$ of their weight and, according to the International Standard ISO 3632 (2011) [7], moisture must be lower than 12\% in order to preserve the spice for a long time [8]. Its quality is based on the capacity of the spice to give colour, taste, and aroma to foods and beverages, and these organoleptic properties are influenced by the dehydration process [8-12]. Saffron colour comes from crocetin esters also known as crocins, its bitter taste from picrocrocin, and its distinctive aroma from safranal [13,14]. Depending on the physical and chemical characteristics of saffron, it is classified into one of the three categories established by the ISO 3632 (2011) standard. This international standard is 
principally used to determine the saffron quality in international commercial agreements, colouring strength being the main parameter from which its price is set. Although the quality of this spice is measured via Ultraviolet-visible (UV-vis) spectrometry, according to ISO 3632 (2011), this method does not provide a precise determination of picrocrocin and safranal concentration [15].

Crocins are a group of water-soluble carotenoids responsible for saffron's colour strength [16-19]. For each crocetin ester, there could be various geometric isomers, trans isomers being the most abundant and more stable than cis [20]. During the dehydration process, safranal is formed from picrocrocin due to high temperatures. It can also be obtained by extreme $\mathrm{pH}$ or a two-step enzymatic process [8,21]. Storage is also a determinant in saffron quality, as safranal concentration is higher in saffron stored longer than one month due to its formation from crocetin esters and picrocrocin during storage time [22,23].

Alternatives to traditional dehydration methods are being researched, as this process is known for being unproductive and slow [24,25]. Some techniques that are studied today are microwave dehydration, oven dehydration, freeze dehydration (lyophilization), vacuum dehydration, and infrared dehydration, among others to be applied to saffron dehydration [26]. These alternative dehydration methods show greater crocin content in freeze dried saffron and in processes where high temperature is applied [5,14]. Microwave dehydration provides great efficiency, controllability over the process, and a higher rate at a lower temperature due to water molecules absorbing the energy and evaporating quickly $[13,27,28]$. Compared to heat dehydration, microwave provides higher speed and volumetric heating, instead of superficial heating on account of traditional dehydration $[29,30]$.

Previous studies have proposed microwave dehydration as a good alternative to traditional dehydration methods, as it provides higher concentrations of safranal and crocins in a shorter time under determinate conditions $[5,6,14]$. However, the effect of microwave dehydration on the main metabolites of saffron has not been studied in depth. Thus, the aim of this work was to study the effect of microwave dehydration on saffron's main metabolites and its commercial quality. To achieve this, the content of the most important compounds in saffron-picrocrocin, safranal, and crocetin esters-were measured after carrying out the microwave dehydration of fresh stigmas at different powers and times, using high performance liquid chromatography-diode array detection (HPLC-DAD) and UV-vis spectrometry.

\section{Materials and Methods}

\subsection{Samples and Reagents}

Fresh stigmas of Crocus sativus L. were purchased from the company "Molineta de Minaya" (Minaya, Spain). The control sample consists of a part of fresh stigmas that were dehydrated according to the own company's internal procedures, considering therefore that this saffron belongs to Protected Designation of Origin (PDO) "Azafrán de La Mancha" [4,31]. Acetonitrile used in HPLC gradient was purchased from Scharlau (Barcelona, Spain). Ultrahigh-purity water was produced using a Milli-Q system (Millipore, Bedford, MA, USA).

\subsection{Dehydration Process}

Fresh stigmas were distributed into 15 portions of $1.5 \mathrm{~g}$ each and placed into a filter paper box. The dehydration process was carried out at low, medium, and high power $(440 \mathrm{~W}, 616 \mathrm{~W}$, and $800 \mathrm{~W}$, respectively) and different time lapses for each ( $36 \mathrm{~s}, 55 \mathrm{~s}, 73 \mathrm{~s}$, and $130 \mathrm{~s}$ for $440 \mathrm{~W} ; 26 \mathrm{~s}, 39 \mathrm{~s}, 52 \mathrm{~s}, 79 \mathrm{~s}, 83 \mathrm{~s}$, and $90 \mathrm{~s}$ for $616 \mathrm{~W} ; 20 \mathrm{~s}, 30 \mathrm{~s}, 40 \mathrm{~s}$, and $60 \mathrm{~s}$ for $800 \mathrm{~W}$ ) in order to control the decrease of humidity and prevent vegetal material from burning out. Between each lapse, a $10 \mathrm{~s}$ rest period was maintained, during which time the mass was measured to monitor weight loss. Time lapses were repeated until weight was reduced by $80 \% \pm 2$, resulting in the total energy applied at every treatment (shown in Table 1). 
Table 1. Dehydration treatments applied to fresh stigmas of Crocus sativus L.

\begin{tabular}{cccccc}
\hline Treatment & Power $(\mathbf{W})$ & $\begin{array}{c}\text { Seconds } \\
\text { (s)/Lapse }\end{array}$ & $\mathbf{N}^{\circ}$ Lapses & Total Time (s) & Joules (J) \\
\hline $440-36$ & 440 & 36 & 6 & 216 & 95,040 \\
$440-55$ & 440 & 55 & 4 & 220 & 96,800 \\
$440-73$ & 440 & 73 & 3 & 219 & 96,360 \\
$440-130$ & 440 & 130 & 2 & 6 & 114,400 \\
\hline $616-26$ & 616 & 26 & 4 & 156 & 96,096 \\
$616-39$ & 616 & 52 & 2 & 144 & 88,704 \\
$616-52$ & 616 & 78 & 2 & 156 & 96,096 \\
$616-79$ & 616 & 83 & 2 & 166 & 96,096 \\
$616-83$ & 616 & 90 & 6 & 180 & 102,256 \\
$616-90$ & 616 & 20 & 5 & 120 & 110,880 \\
\hline $800-20$ & 800 & 30 & 3 & 150 & 96,000 \\
$800-30$ & 800 & 40 & 2 & 120 & 120,000 \\
$800-40$ & 800 & 60 & & 96,000 \\
$800-60$ & 800 & & 36 & 96,000 \\
\hline
\end{tabular}

\subsection{Saffron Extract Preparation}

The saffron extracts were prepared according to ISO 3632 (2011) [7] slightly modified. They were then ground to a powder and passed through a sieve $0.5 \mathrm{~mm}$ in pore diameter; $50 \mathrm{mg}$ was then placed in a $100 \mathrm{~mL}$ flask, adding $90 \mathrm{~mL}$ of Milli-Q water. The solution was stirred for $1 \mathrm{~h}$ at $1000 \mathrm{rpm}$ using a magnetic stir bar in the dark. The flask was filled to $100 \mathrm{~mL}$ and homogenised through agitation. The solution was filtered through a $0.45 \mu \mathrm{m}$ pore sized hydrophilic polytetrafluoroethylene (PTFE) filter (Millipore, Bedford, MA, USA). Two extracts were obtained from each dehydration treatment, including the control.

\subsection{Nomenclature for Crocetin Esters}

Abbreviations for crocetin esters were adopted from Carmona et al. [20]: trans-5$\mathrm{tG}$, trans-crocetin (tri- $\beta$-D-glucosyl)-( $\beta$-D-gentibiosyl) ester; trans-5-nG, trans-crocetin ( $\beta$ D-neapolitanosyl)-( $\beta$-D-gentibiosyl) ester; trans-4-GG, trans-crocetin di-( $\beta$-D-gentibiosyl) ester; trans-4-ng, trans-crocetin ( $\beta$-D-neapolitanosyl)-( $\beta$-D-glucosyl) ester; trans-3-Gg, transcrocetin ( $\beta$-D-glucosyl)-( $\beta$-D-gentibiosyl) ester; trans-2-gg, trans-crocetin di-( $\beta$-D-glucosyl) ester; cis-4-GG, cis-crocetin di-( $\beta$-D-gentibiosyl) ester; trans-2-G, trans-crocetin ( $\beta$-D-gentibiosyl) ester; cis-3-Gg, cis-crocetin ( $\beta$-D-glucosyl)-( $\beta$-D-gentibiosyl) ester; trans-1-g, trans-crocetin ( $\beta$-D-glucosyl) ester.

\subsection{HPLC-DAD Analysis}

This analysis was performed according to the method by García-Rodríguez et al. [11]. $20 \mu \mathrm{L}$ of each sample was injected into the Agilent 1200 HPLC chromatograph (Palo Alto, CA, USA) equipped with a $250 \mathrm{~mm} \times 4.6 \mathrm{~mm}$ diameter, $5 \mu \mathrm{m}$ Develosil Octadecyl SystemTrifunctional (ODS-HG-5) chromatographic column (Teknokroma, Sant Cugat del Vallès, Barcelona, Spain) equilibrated at $40{ }^{\circ} \mathrm{C}$. The eluents were water (A) and acetonitrile (B) with the following gradients: $20 \% \mathrm{~B}, 0-5 \mathrm{~min} ; 20-80 \% \mathrm{~B}, 5-15 \mathrm{~min}$; and $80 \% \mathrm{~B}, 15-20 \mathrm{~min}$ at $0.8 \mathrm{~mL} / \mathrm{min}$ of flow rate. The DAD detector (Hewlett Packard, Waldbronn, Germany) was set at 250,330 , and $440 \mathrm{~nm}$ to detect picrocrocin, safranal, and crocetin esters, respectively. All analyses were performed in duplicate for each replicate $(n=4)$.

Identification of crocetin esters, picrocrocin, and safranal was carried out as previously reported $[11,16]$. Quantification was based on the following calibration curves [11]: $C_{i}=(0.00746 \pm 0.00004) A_{i}-(0.00571 \pm 0.12863)$, correlation coefficient $\left(R^{2}\right)=0.9999$ for trans-5-tG, trans-5-nG, trans-4-GG and trans- $4-\mathrm{ng} ; \mathrm{C}_{\mathrm{i}}=(0.00713 \pm 0.00003) \mathrm{A}_{\mathrm{i}}-(0.00472$ $\pm 0.05608), R^{2}=0.9999$ for trans-3-Gg, trans-2-gg, trans-2-G and trans-1-g; $C_{i}=(0.00531$ $\pm 0.0004) \mathrm{A}_{\mathrm{i}}-(0.00571 \pm 0.12863), \mathrm{R}^{2}=0.9999$ for cis-4-GG; $\mathrm{C}_{\mathrm{i}}=(0.00500 \pm 0.00003) \mathrm{A}_{\mathrm{i}}$ $-(0.00331 \pm 0.05608), R^{2}=0.9999$ for cis-3-Gg; $C_{i}=(0.02900 \pm 0.00002) A_{i}+(0.51940 \pm$ $0.02631), R^{2}=0.9999$ for picrocrocin, and $C_{i}=(0.03227 \pm 0.00063) A_{i}+(0.05101 \pm 0.03103)$, 
$\mathrm{R}^{2}=0.9989$ for safranal. Limits of detection (LOD) and quantification (LOQ) were taken into consideration [11].

\subsection{UV-Vis Spectrometry}

In order to perform UV-vis spectrometry analysis according to ISO 3632 (2011) [7], the same extract used for HPLC-DAD analysis was diluted to 1:10 $(v / v)$ and then scanned by duplicate at a wavelength of 440, 330, and $257 \mathrm{~nm}$ by a Perkin Elmer Lambda 20 UV-Vis spectrophotometer (Perkin Elmer, Norwalk, CT, USA) in a $1 \mathrm{~cm}$ pathway quartz cell.

\subsection{Statistical Analysis}

The statistical analysis was performed using SPSS Statistics 25 for Windows (IBM, Armond, NY, USA). Data were analysed by performing one-way analysis of variance (ANOVA), with Duncan's test for multiple comparisons and Dependent $t$-test for paired samples with degree of freedom of 3 , considering $p<0.05$ as statistically significant $(95 \%$ confidence interval).

\section{Results and Discussion}

\subsection{Content of the Main Metabolites of Microwave-Dehydrated Saffron}

To determine the effect of microwave dehydration on saffron's main metabolites, the stigmas were dehydrated at different powers and time lapses, and subsequently analysed through HPLC-DAD, which is the only way to determine these compounds [11].

Picrocrocin, safranal, and crocetin esters concentrations are shown in Table 2. With regards to picrocrocin, the first metabolite to be detected in the analysis, control values were significantly higher in traditional dehydration than the microwave treatments. Safranal was not quantified in traditional "toasting" because its content was below the limit of quantification. However, all microwave dehydration treatments showed safranal. Tong et al. [6] observed that an increase in the time of microwave dehydration of fresh stigmas (from 3 to $6 \mathrm{~min}$ ) at $600 \mathrm{~W}$ registered a decrease of safranal concentration, while at $450 \mathrm{~W}$ a longer time (from 6 to $10 \mathrm{~min}$ ) obtained a higher concentration. In our study, it is essential to supply an energy of the same order by combining powers and times (providing different time lapses), so that within each power studied there is no great difference in total time to be able to compare our results with those showed by these authors. Another study described the effect on different dehydration methods, including microwave dehydration [14], in which safranal reported the highest concentration in compared to electric oven dehydration and vacuum oven dehydration; however, the results in the mentioned study cannot be compared to ours as the dehydration time employed was excessive $(1.9 \mathrm{~h})$.

The total content of crocetin esters showed significant variances between the control and the other microwave treatments, except for 440-36, 440-130, 616-39, 616-52, and 800-20. This also happened in the sum of trans crocetin esters with the exception for the treatment 440-130, which also showed significant differences to the control. The cis isomers showed significant differences in microwave-treated samples against the control, and those samples which showed the highest concentration of cis isomers were also the ones that had the highest safranal concentration. In this sense, Carmona et al. [23] reported that a high temperature for the dehydration process promotes the isomerization of trans crocetin esters to cis, as well as safranal synthesis from these carotenoids and picrocrocin. Speranza and Dadá [32] observed the formation of 13-cis-crocin, after $1 \mathrm{~h}$ of exposition to light. On the other hand, this is the first time that the concentration of the main metabolites of stigmas dehydrated by microwave is evaluated in detail. There is no previous study showing the concentration of trans and cis isomers, which could be used to compare our results, but it seems that the energy supplied by microwave dehydration of stigmas may be involved in the formation of cis crocetin esters. Thus, all these results could indicate that different energy sources could influence the isomerization process and the formation of safranal from picrocrocin and the cycling of cis isomers. 
Table 2. Content of the main compounds of saffron obtained under different microwave dehydration treatments.

\begin{tabular}{ccccccc}
\hline \multirow{2}{*}{ Treatment } & \multicolumn{5}{c}{ Compounds (g/kg Saffron \pm SD) } \\
\cline { 2 - 6 } & Picrocrocin & Safranal & Total CE & $\sum$ Trans-CE & $\sum$ Cis-CE & Trans/Cis \\
\hline Control & $244.2 \pm 8.9 \mathrm{i}$ & $<$ LOQ & $262.7 \pm 8.7 \mathrm{f}$ & $260.4 \pm 8.9 \mathrm{f}$ & $2.35 \pm 0.17 \mathrm{a}$ & $113 \pm 12 \mathrm{~g}$ \\
\hline $440-36$ & $215.4 \pm 0.1 \mathrm{e}-\mathrm{g}$ & $0.41 \pm 0.03 \mathrm{ab}$ & $252.0 \pm 1.7 \mathrm{ef}$ & $245.3 \pm 1.6 \mathrm{~d}-\mathrm{f}$ & $6.70 \pm 0.14 \mathrm{de}$ & $37 \pm 1 \mathrm{de}$ \\
$440-55$ & $192.6 \pm 3.2 \mathrm{bc}$ & $0.71 \pm 0.07 \mathrm{bc}$ & $239.1 \pm 6.4 \mathrm{~b}-\mathrm{e}$ & $231.8 \pm 6.1 \mathrm{~b}-\mathrm{e}$ & $7.30 \pm 0.37 \mathrm{e}$ & $32 \pm 1 \mathrm{~cd}$ \\
$440-73$ & $174.6 \pm 2.9 \mathrm{a}$ & $1.97 \pm 0.15 \mathrm{f}$ & $226.6 \pm 2.8 \mathrm{a}-\mathrm{c}$ & $216.3 \pm 2.6 \mathrm{ab}$ & $10.35 \pm 0.36 \mathrm{fg}$ & $21 \pm 1 \mathrm{ab}$ \\
$440-130$ & $201.3 \pm 0.4 \mathrm{~cd}$ & $0.40 \pm 0.01 \mathrm{ab}$ & $248.9 \pm 1.5 \mathrm{~d}-\mathrm{f}$ & $242.4 \pm 1.5 \mathrm{c}-\mathrm{e}$ & $6.43 \pm 0.05 \mathrm{de}$ & $38 \pm 1 \mathrm{~d}-\mathrm{f}$ \\
\hline $616-26$ & $208.4 \pm 3.8 \mathrm{~d}-\mathrm{f}$ & $0.90 \pm 0.11 \mathrm{~cd}$ & $243.4 \pm 7.6 \mathrm{c}-\mathrm{e}$ & $235.6 \pm 7.6 \mathrm{c}-\mathrm{e}$ & $7.72 \pm 0.10 \mathrm{e}$ & $31 \pm 1 \mathrm{~b}-\mathrm{d}$ \\
$616-39$ & $217.9 \pm 0.4 \mathrm{fg}$ & $1.39 \pm 0.20 \mathrm{e}$ & $250.9 \pm 3.9 \mathrm{~d}-\mathrm{f}$ & $244.2 \pm 3.9 \mathrm{~d}-\mathrm{f}$ & $6.71 \pm 0.28 \mathrm{de}$ & $37 \pm 2 \mathrm{de}$ \\
$616-52$ & $221.7 \pm 2.2 \mathrm{~g}$ & $1.34 \pm 0.15 \mathrm{e}$ & $255.2 \pm 4.0 \mathrm{ef}$ & $248.7 \pm 4.2 \mathrm{ef}$ & $6.53 \pm 0.26 \mathrm{de}$ & $38 \pm 2 \mathrm{~d}-\mathrm{f}$ \\
$616-79$ & $202.6 \pm 2.0 \mathrm{~cd}$ & $0.23 \pm 0.02 \mathrm{a}$ & $231.0 \pm 6.0 \mathrm{a}-\mathrm{c}$ & $225.1 \pm 5.8 \mathrm{a}-\mathrm{c}$ & $5.94 \pm 0.17 \mathrm{~cd}$ & $38 \pm 1 \mathrm{~d}-\mathrm{f}$ \\
$616-83$ & $177.8 \pm 2.7 \mathrm{a}$ & $0.21 \pm 0.03 \mathrm{a}$ & $216.9 \pm 6.0 \mathrm{a}$ & $212.5 \pm 5.9 \mathrm{a}$ & $4.47 \pm 0.30 \mathrm{~b}$ & $48 \pm 3 \mathrm{f}$ \\
$616-90$ & $174.3 \pm 2.0 \mathrm{a}$ & $0.41 \pm 0.04 \mathrm{ab}$ & $221.6 \pm 3.8 \mathrm{ab}$ & $214.7 \pm 3.6 \mathrm{ab}$ & $6.93 \pm 0.19 \mathrm{de}$ & $31 \pm 2 \mathrm{~b}-\mathrm{d}$ \\
\hline $800-20$ & $233.7 \pm 2.7 \mathrm{~h}$ & $1.15 \pm 0.14 \mathrm{de}$ & $252.7 \pm 8.5 \mathrm{ef}$ & $245.7 \pm 8.2 \mathrm{~d}-\mathrm{f}$ & $7.00 \pm 0.37 \mathrm{de}$ & $35 \pm 1 \mathrm{e}$ \\
$800-30$ & $207.3 \pm 0.7 \mathrm{de}$ & $2.25 \pm 0.22 \mathrm{f}$ & $238.3 \pm 3.6 \mathrm{~b}-\mathrm{e}$ & $228.4 \pm 3.6 \mathrm{a}-\mathrm{d}$ & $9.97 \pm 0.78 \mathrm{f}$ & $23 \pm 2 \mathrm{a}-\mathrm{c}$ \\
$800-40$ & $202.2 \pm 0.2 \mathrm{~cd}$ & $2.69 \pm 0.35 \mathrm{~g}$ & $227.5 \pm 4.1 \mathrm{a}-\mathrm{c}$ & $216.2 \pm 4.5 \mathrm{ab}$ & $11.36 \pm 0.99 \mathrm{~g}$ & $20 \pm 2 \mathrm{a}$ \\
$800-60$ & $188.7 \pm 4.4 \mathrm{~b}$ & $0.38 \pm 0.05 \mathrm{ab}$ & $233.4 \pm 6.6 \mathrm{a}-\mathrm{d}$ & $228.4 \pm 6.4 \mathrm{a}-\mathrm{d}$ & $4.97 \pm 0.19 \mathrm{bc}$ & $46 \pm 1 \mathrm{ef}$ \\
\hline
\end{tabular}

$\mathrm{LOQ}=$ limit of quantification. Total $\mathrm{CE}=$ Total crocetin esters. $\sum$ trans-CE $=$ sum of trans isomers of crocetin esters. $\sum$ cis-CE $=$ sum of cis isomers of crocetin esters. Values are the mean of two extracts conducted in duplicate $(2 \times 2 \mathrm{n}), \mathrm{SD}=$ standard deviation. One-way analysis of variance (ANOVA) for each column is included. Different letters within each column represent statistically significant variances, according to Duncan test $(p<0.05)$.

The proportion between trans and cis crocetin esters was analysed, showing that trans crocetin esters are the predominant form of crocins. All the microwave-treated samples showed significant variance with the control, the values of which ranged from 20 in 800-40 to 48 in 616-83. Therefore, the saffron obtained by microwave dehydration contains less content of trans crocetin esters than those obtained from traditional "toasting", resulting in saffron with less bioactive capacity, as trans crocetin esters compounds are more bioactive than cis isomers $[3,12,33]$.

Crocins are a wide group of glycosyl esters, of which the predominant ones are trans-4-GG and trans-3-Gg. Concentration values of the crocetin esters are shown in Table 3. One of the predominant crocetin esters is trans-4-GG, which showed differences to the control in all microwave dehydration treatments, except for 440-73, 616-83, 616-90, and 800-40. The other main crocetin ester is trans-3-Gg, which showed the highest concentration values of all the reported glycosides and obtained significant differences between the control and all the microwave dehydration treatments studied. Previous studies showed that trans-4-GG concentration is higher than trans-3-Gg in traditionally dehydrated stigmas $[11,16,34,35]$. Other works are in accordance with our results as a greater value of trans-3-Gg concentration than trans-4-GG is also registered when stigmas are dried in the shade or freeze-dried [35,36]. However, under these different methods of dehydration, contrary results have also been obtained [36,37]. Therefore, it can be mentioned that these two compounds are the main crocetin esters of saffron.

In the other crocetin esters studied, significant differences to the control were shown for trans-5-nG, trans-2-gg, trans-2-G and trans-1-g. All these compounds showed higher content in control except for trans-1-g, whose content was higher in all the microwave treatments [3]. 
Table 3. : Crocetin esters content of saffron obtained by different dehydration treatments.

\begin{tabular}{|c|c|c|c|c|c|c|c|c|c|c|}
\hline \multirow{2}{*}{ Treatment } & \multicolumn{10}{|c|}{ Compounds (g/kg Saffron \pm SD) } \\
\hline & Trans-5-tG & Trans-5-nG & Trans-4-GG & Trans-4-ng & Trans-3-Gg & Trans-2-gg & Cis-4-GG & Trans-2-G & Cis-3-Gg & Trans-1-g \\
\hline Control & $0.33 \pm 0.09 \mathrm{ab}$ & $1.18 \pm 0.12 \mathrm{e}$ & $90.2 \pm 4.3 \mathrm{a}$ & $1.37 \pm 0.15 \mathrm{a}$ & $125.8 \pm 4.5 \mathrm{~d}$ & $39.11 \pm 4.62 \mathrm{~d}$ & $1.39 \pm 0.11 \mathrm{a}$ & $2.26 \pm 0.57 b$ & $0.96 \pm 0.08$ a & $0.16 \pm 0.01 \mathrm{a}$ \\
\hline $440-36$ & $0.83 \pm 0.02 \mathrm{f}$ & $0.37 \pm 0.02 \mathrm{a}-\mathrm{d}$ & $107.9 \pm 0.6 \mathrm{e}$ & $2.08 \pm 0.16 b c$ & $113.1 \pm 1.9 \mathrm{c}$ & $20.62 \pm 0.32 \mathrm{a}-\mathrm{c}$ & $4.20 \pm 0.06 \mathrm{de}$ & $<\mathrm{LOD}$ & $2.50 \pm 0.09 \mathrm{~d}-\mathrm{f}$ & $0.42 \pm 0.01 g$ \\
\hline $440-55$ & $0.45 \pm 0.05 \mathrm{a}-\mathrm{c}$ & $0.24 \pm 0.03 \mathrm{a}-\mathrm{c}$ & $97.5 \pm 1.3 b c$ & $1.63 \pm 0.16 \mathrm{ab}$ & $110.8 \pm 3.9 c$ & $20.74 \pm 1.36 \mathrm{a}-\mathrm{c}$ & $4.50 \pm 0.18 \mathrm{de}$ & $<$ LOD & $2.80 \pm 0.19 \mathrm{fg}$ & $0.46 \pm 0.01 \mathrm{~h}$ \\
\hline $440-73$ & $0.38 \pm 0.04 \mathrm{ab}$ & $0.14 \pm 0.04 \mathrm{a}$ & $94.6 \pm 0.4 \mathrm{ab}$ & $1.85 \pm 0.20 \mathrm{a}-\mathrm{c}$ & $97.5 \pm 2.0 \mathrm{a}$ & $21.38 \pm 0.38 \mathrm{bc}$ & $6.49 \pm 0.18 \mathrm{f}$ & $<$ LOD & $3.86 \pm 0.18 \mathrm{~h}$ & $0.46 \pm 0.00 \mathrm{~b}$ \\
\hline $440-130$ & $0.73 \pm 0.01$ ef & $0.33 \pm 0.02 \mathrm{a}-\mathrm{d}$ & $104.9 \pm 0.1 \mathrm{de}$ & $2.32 \pm 0.13 c$ & $111.6 \pm 1.3 \mathrm{c}$ & $21.48 \pm 0.20 \mathrm{bc}$ & $3.98 \pm 0.03 \mathrm{~cd}$ & $0.53 \pm 0.02 \mathrm{a}$ & $2.45 \pm 0.01 \mathrm{~d}-\mathrm{f}$ & $0.54 \pm 0.01 \mathrm{i}$ \\
\hline $616-26$ & $0.67 \pm 0.07$ ef & $0.43 \pm 0.09 \mathrm{~cd}$ & $101.4 \pm 2.2 \mathrm{~cd}$ & $1.54 \pm 0.13 \mathrm{ab}$ & $108.3 \pm 4.1 \mathrm{bc}$ & $22.17 \pm 1.02 c$ & $5.13 \pm 0.14 \mathrm{e}$ & $0.73 \pm 0.17 \mathrm{a}$ & $2.59 \pm 0.05 \mathrm{ef}$ & $0.37 \pm 0.01 \mathrm{f}$ \\
\hline $616-39$ & $0.71 \pm 0.06$ ef & $0.43 \pm 0.07 \mathrm{~cd}$ & $105.5 \pm 0.6 \mathrm{de}$ & $1.75 \pm 0.19 a-c$ & $112.0 \pm 2.8 c$ & $22.82 \pm 0.57 c$ & $4.47 \pm 0.21 \mathrm{de}$ & $0.72 \pm 0.20 \mathrm{a}$ & $2.24 \pm 0.12 \mathrm{c}-\mathrm{e}$ & $0.29 \pm 0.01 \mathrm{c}$ \\
\hline $616-79$ & $0.67 \pm 0.04 \mathrm{ef}$ & $0.46 \pm 0.03 \mathrm{~cd}$ & $101.5 \pm 1.7 \mathrm{~cd}$ & $1.54 \pm 0.04 \mathrm{ab}$ & $100.5 \pm 3.2 \mathrm{ab}$ & $19.31 \pm 0.97 \mathrm{a}-\mathrm{c}$ & $3.88 \pm 0.10 \mathrm{~cd}$ & $0.72 \pm 0.02 \mathrm{a}$ & $2.06 \pm 0.07 \mathrm{~cd}$ & $0.34 \pm 0.01 \mathrm{e}$ \\
\hline $616-83$ & $0.44 \pm 0.04 \mathrm{a}-\mathrm{c}$ & $0.20 \pm 0.05 \mathrm{ab}$ & $95.7 \pm 1.8 \mathrm{a}-\mathrm{c}$ & $1.37 \pm 0.14 \mathrm{a}$ & $97.4 \pm 3.3 \mathrm{a}$ & $16.62 \pm 0.90 \mathrm{a}$ & $2.86 \pm 0.19 \mathrm{~b}$ & $0.45 \pm 0.04 \mathrm{a}$ & $1.61 \pm 0.12 \mathrm{~b}$ & $0.32 \pm 0.00 \mathrm{e}$ \\
\hline $616-90$ & $0.30 \pm 0.02 \mathrm{a}$ & $0.17 \pm 0.02 \mathrm{a}$ & $94.3 \pm 1.0 \mathrm{ab}$ & $1.37 \pm 0.07 \mathrm{a}$ & $100.5 \pm 2.2 \mathrm{ab}$ & $17.09 \pm 0.49 \mathrm{ab}$ & $4.33 \pm 0.08 \mathrm{de}$ & $0.44 \pm 0.02 \mathrm{a}$ & $2.60 \pm 0.11$ ef & $0.55 \pm 0.05 \mathrm{i}$ \\
\hline $800-20$ & $0.64 \pm 0.06 \mathrm{de}$ & $0.56 \pm 0.10 \mathrm{~d}$ & $105.2 \pm 2.9 \mathrm{de}$ & $1.84 \pm 0.27 \mathrm{a}-\mathrm{c}$ & $114.9 \pm 4.2 \mathrm{c}$ & $21.89 \pm 1.10 c$ & $4.66 \pm 0.25 \mathrm{de}$ & $0.43 \pm 0.06 \mathrm{a}$ & $2.33 \pm 0.14 \mathrm{de}$ & $0.22 \pm 0.01 \mathrm{~b}$ \\
\hline $800-30$ & $0.50 \pm 0.04 b-d$ & $0.42 \pm 0.10 \mathrm{~b}-\mathrm{d}$ & $98.4 \pm 1.0 \mathrm{bc}$ & $1.75 \pm 0.20 \mathrm{a}-\mathrm{c}$ & $105.1 \pm 2.2 \mathrm{a}-\mathrm{c}$ & $21.42 \pm 0.40 \mathrm{bc}$ & $6.93 \pm 0.76 \mathrm{fg}$ & $0.52 \pm 0.13 \mathrm{a}$ & $3.04 \pm 0.02 \mathrm{~g}$ & $0.25 \pm 0.01 \mathrm{c}$ \\
\hline $800-40$ & $0.40 \pm 0.08 \mathrm{ab}$ & $0.35 \pm 0.08 \mathrm{a}-\mathrm{d}$ & $95.2 \pm 1.7 \mathrm{ab}$ & $1.70 \pm 0.22 \mathrm{ab}$ & $96.4 \pm 2.6 \mathrm{a}$ & $21.11 \pm 0.33 \mathrm{a}-\mathrm{c}$ & $7.66 \pm 0.70 \mathrm{~g}$ & $0.80 \pm 0.27 a$ & $3.70 \pm 0.37 \mathrm{~h}$ & $0.25 \pm 0.01 \mathrm{c}$ \\
\hline $800-60$ & $0.60 \pm 0.06 \mathrm{c}-\mathrm{e}$ & $0.33 \pm 0.08 \mathrm{a}-\mathrm{d}$ & $100.3 \pm 1.7 \mathrm{~b}-\mathrm{d}$ & $1.49 \pm 0.14 \mathrm{ab}$ & $104.8 \pm 3.9 \mathrm{a}-\mathrm{c}$ & $20.26 \pm 0.72 \mathrm{a}-\mathrm{c}$ & $3.14 \pm 0.14 b c$ & $0.39 \pm 0.02 \mathrm{a}$ & $1.83 \pm 0.05 b c$ & $0.26 \pm 0.00 c$ \\
\hline
\end{tabular}

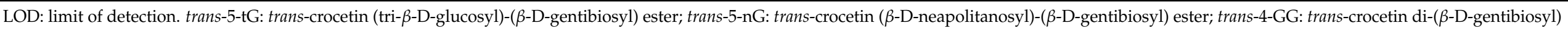

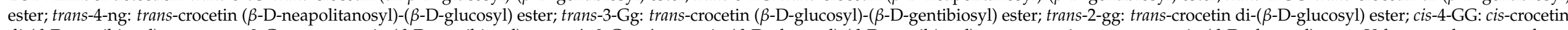

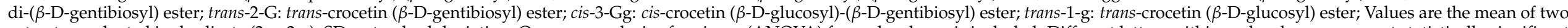

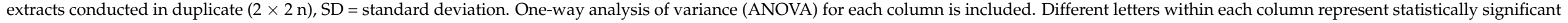
variances, according to Duncan test $(p<0.05)$. 
Cis-4-GG and cis-3-Gg were the cis-crocetin esters identified and quantified in this work. Both showed significant differences to the control with higher content in the treatments studied. These crocetin esters are known for being less bioactive than the trans esters, which results in a saffron with lower bioactive capacity.

Saffron aroma is enhanced after at least a month of its storage in stigmas traditionally dehydrated, the reason why saffron is not sold immediately after dehydration. In addition, previous studies observed that saffron's main compounds' content evolves over time [4,35]. Thus, microwave dehydrated saffron was stored for three months in order to study the evolution of the main metabolites, after which these compounds were analysed by HPLCDAD again.

Picrocrocin, safranal, and total crocetin esters concentration after three months of storage are shown in Table 4. Both picrocrocin and safranal maintained the significant differences shown between the control and the treatments studied before the storage. In practically all dehydration parameters studied, safranal values were higher after storage, which matches with the previous results of storage effect on safranal according to Maggi et al. [38]. Moreover, Sereshti et al. [39] reported that safranal content is lower in freshly dried stigmas, and at least a month of storage is known to be necessary for the development of saffron aroma [22,23].

Table 4. Content of the main compounds of saffron obtained under different dehydration treatments after being stored for three months.

\begin{tabular}{ccccccc}
\hline \multirow{2}{*}{ Treatment } & \multicolumn{5}{c}{ Compounds (g/kg Saffron \pm SD) } \\
\cline { 2 - 6 } & Picrocrocin & Safranal & Total CE & $\sum$ Trans-CE & $\sum$ Cis-CE & Trans/Cis \\
\hline Control & $247.3 \pm 3.9 \mathrm{~g} *$ & $0.33 \pm 0.11 \mathrm{a}$ & $232.2 \pm 8.5 \mathrm{de}$ & $231.2 \pm 8.5 \mathrm{ef}$ & $1.04 \pm 0.03 \mathrm{a}$ & $223 \pm 1 \mathrm{~h}$ \\
\hline $440-36$ & $212.5 \pm 2.1 \mathrm{e}$ & $0.88 \pm 0.01 \mathrm{bc}$ & $268.2 \pm 1.5 \mathrm{~g}$ & $264.3 \pm 1.6 \mathrm{hi}$ & $3.90 \pm 0.14 \mathrm{c}$ & $68 \pm 3 \mathrm{f}$ \\
$440-55$ & $209.4 \pm 1.0 \mathrm{e}$ & $0.81 \pm 0.00 \mathrm{~b}$ & $266.6 \pm 7.2 \mathrm{~g}$ & $262.8 \pm 6.9 \mathrm{hi}$ & $3.76 \pm 0.29 \mathrm{c}$ & $71 \pm 4 \mathrm{f}$ \\
$440-73$ & $195.0 \pm 0.2 \mathrm{e}$ & $1.59 \pm 0.00 \mathrm{f}$ & $254.9 \pm 0.4 \mathrm{~g}$ & $249.9 \pm 0.3 \mathrm{i}$ & $5.03 \pm 0.02 \mathrm{e}$ & $50 \pm 1 \mathrm{e}$ \\
$440-130$ & $186.6 \pm 2.5 \mathrm{~b}$ & $1.24 \pm 0.02 \mathrm{~d}$ & $238.8 \pm 2.7 \mathrm{e}$ & $235.9 \pm 2.5 \mathrm{fg}$ & $2.90 \pm 0.16 \mathrm{~b}$ & $82 \pm 4 \mathrm{~g}$ \\
\hline $616-26$ & $208.4 \pm 0.1 \mathrm{de} *$ & $0.98 \pm 0.01 \mathrm{c} *$ & $226.3 \pm 1.0 \mathrm{c}-\mathrm{e}$ & $219.0 \pm 0.8 \mathrm{c}-\mathrm{e}$ & $7.28 \pm 0.19 \mathrm{f}$ & $30 \pm 1 \mathrm{bc}$ \\
$616-39$ & $203.1 \pm 1.3 \mathrm{c}-\mathrm{e}$ & $1.76 \pm 0.02 \mathrm{~g}$ & $215.2 \pm 2.6 \mathrm{c}$ & $207.3 \pm 2.4 \mathrm{c}$ & $7.87 \pm 0.12 \mathrm{f}$ & $26 \pm 0 \mathrm{~b}$ \\
$616-52$ & $197.8 \pm 0.5 \mathrm{~b}-\mathrm{d}$ & $1.65 \pm 0.01 \mathrm{fg}$ & $220.6 \pm 0.5 \mathrm{~cd}$ & $212.8 \pm 0.4 \mathrm{~cd}$ & $7.79 \pm 0.16 \mathrm{f}$ & $27 \pm 1 \mathrm{~b}$ \\
$616-79$ & $189.0 \pm 0.7 \mathrm{~b}$ & $0.78 \pm 0.00 \mathrm{~b}$ & $174.1 \pm 4.9 \mathrm{~b}$ & $169.7 \pm 4.8 \mathrm{~b}$ & $4.40 \pm 0.04 \mathrm{~cd}$ & $39 \pm 1 \mathrm{~d} *$ \\
$616-83$ & $158.1 \pm 2.5 \mathrm{a}$ & $1.45 \pm 0.02 \mathrm{e}$ & $130.8 \pm 1.7 \mathrm{a}$ & $126.7 \pm 1.5 \mathrm{a}$ & $4.07 \pm 022 \mathrm{~cd} *$ & $31 \pm 1 \mathrm{bc}$ \\
$616-90$ & $197.4 \pm 0.1 \mathrm{bc}$ & $1.18 \pm 0.00 \mathrm{~d}$ & $275.1 \pm 0.5 \mathrm{fg}$ & $267.1 \pm 0.5 \mathrm{gh}$ & $7.77 \pm 0.12 \mathrm{f}$ & $34 \pm 1 \mathrm{bc}$ \\
\hline $800-20$ & $235.6 \pm 7.0 \mathrm{f} *$ & $1.59 \pm 0.29 \mathrm{f}$ & $262.0 \pm 3.3 \mathrm{~g} *$ & $252.5 \pm 3.3 \mathrm{hi} *$ & $9.54 \pm 0.07 \mathrm{~g}$ & $26 \pm 0 \mathrm{~b}$ \\
$800-30$ & $205.7 \pm 2.9 \mathrm{de} *$ & $3.59 \pm 0.04 \mathrm{~h}$ & $241.6 \pm 3.6 \mathrm{ef} *$ & $228.2 \pm 3.1 \mathrm{~d}-\mathrm{f} *$ & $13.37 \pm 0.51 \mathrm{~h}$ & $17 \pm 0 \mathrm{a}$ \\
$800-40$ & $193.2 \pm 1.7 \mathrm{bc}$ & $3.82 \pm 0.09 \mathrm{i}$ & $233.8 \pm 3.5 \mathrm{de} *$ & $218.9 \pm 3.0 \mathrm{c}-\mathrm{e}^{*}$ & $14.85 \pm 0.51 \mathrm{i}$ & $15 \pm 0 \mathrm{a}$ \\
$800-60$ & $161.5 \pm 1.8 \mathrm{a}$ & $1.42 \pm 0.04 \mathrm{e}$ & $164.4 \pm 0.7 \mathrm{~b}$ & $159.6 \pm 0.7 \mathrm{~b}$ & $4.81 \pm 0.04 \mathrm{~d}{ }^{*}$ & $33 \pm 0 \mathrm{c}$ \\
\hline
\end{tabular}

Total CE: Total crocetin esters. $\sum$ trans-CE: sum of trans isomers of crocetin esters. $\sum$ cis-CE: sum of cis isomers of crocetin esters. Values are the mean of two extracts conducted in duplicate $(2 \times 2 \mathrm{n}), \mathrm{SD}=$ standard deviation. One-way analysis of variance (ANOVA) for each column is included. Different letters within each column represent statistically significant variances, according to Duncan test $(p<0.05)$. Data marked with * does not show significant variances to same treatment and compound before storage $(p<0.05)$.

The content of total crocetin esters was less in the control and in some microwave dehydration treatments compared to the results obtained before its storage. The treatment 616-83 showed significant variances with the rest of the microwave dehydration treatments and with the control for total crocetin esters and for the sum of trans crocetin esters. All dehydration treatments showed significantly higher cis content than the control, resulting in a lower trans/cis proportion. The treatments that showed the highest concentration of total cis isomers also registered the highest safranal content, which was also observed before the storage, reinforcing the previously mentioned relationship between safranal and cis crocetin esters.

Crocetin esters were analysed after three months of storage to analyse whether deterioration of these compounds had taken place. Main crocetin esters' concentration values are shown in Table 5. 
Table 5. Crocetin esters content of saffron obtained under different dehydration treatments after being stored for three months.

\begin{tabular}{|c|c|c|c|c|c|c|c|c|c|c|}
\hline \multirow{2}{*}{ Treatment } & \multicolumn{10}{|c|}{ Compounds (g/kg Saffron \pm SD) } \\
\hline & Trans-5-tG & Trans-5-nG & Trans-4-GG & Trans-4-ng & Trans-3-Gg & Trans-2-gg & Cis-4-GG & Trans-2-G & Cis-3-Gg & Trans-1-g \\
\hline Control & $0.43 \pm 0.03 \mathrm{bc}^{*}$ & $1.44 \pm 0.02 \mathrm{i}$ & $90.0 \pm 1.1 \mathrm{c}^{*}$ & $1.20 \pm 0.07 c^{*}$ & $110.4 \pm 6.2$ ef & $4.75 \pm 0.73 \mathrm{~d}$ & $1.04 \pm 0.10 \mathrm{a}$ & $21.32 \pm 0.26 \mathrm{~g}$ & $<\mathrm{LOD}$ & $1.67 \pm 0.18 \mathrm{~d}$ \\
\hline $440-36$ & $0.85 \pm 0.02 \mathrm{f} *$ & $0.74 \pm 0.04 \mathrm{gh}$ & $115.0 \pm 1.1 \mathrm{~g}$ & $1.80 \pm 0.12 \mathrm{de}^{*}$ & $121.7 \pm 0.8 \mathrm{~g}$ & $2.88 \pm 0.33 c$ & $3.90 \pm 0.14 \mathrm{c}$ & $20.16 \pm 0.11 \mathrm{~g}$ & $<\mathrm{LOD}$ & $1.24 \pm 0.05 \mathrm{bc}$ \\
\hline $440-55$ & $0.77 \pm 0.02$ ef & $0.69 \pm 0.02 \mathrm{f}-\mathrm{h}$ & $114.6 \pm 1.2 \mathrm{~g}$ & $2.02 \pm 0.10 \mathrm{de}$ & $122.9 \pm 4.5 \mathrm{~g}$ & $2.53 \pm 0.20 b c$ & $3.76 \pm 0.29 c$ & $18.25 \pm 0.88 \mathrm{f}$ & $<\mathrm{LOD}$ & $1.11 \pm 0.09 \mathrm{~b}$ \\
\hline $440-73$ & $0.72 \pm 0.00 \mathrm{f}$ & $0.57 \pm 0.00 \mathrm{gh}$ & $110.2 \pm 2.9 \mathrm{~g}$ & $2.22 \pm 0.01 \mathrm{f}$ & $111.5 \pm 0.2 \mathrm{~g}$ & $2.36 \pm 0.01 \mathrm{c}$ & $5.03 \pm 0.02 \mathrm{f}$ & $21.05 \pm 0.04 \mathrm{~h}$ & $<\mathrm{LOD}$ & $1.28 \pm 0.00 \mathrm{c}$ \\
\hline $440-130$ & $0.65 \pm 0.01 \mathrm{df}$ & $0.58 \pm 0.02$ ef & $105.3 \pm 0.4 \mathrm{f}^{*}$ & $1.86 \pm 0.02$ de & $107.4 \pm 1.7 \mathrm{de}$ & $2.52 \pm 0.10 \mathrm{bc}$ & $2.90 \pm 0.16 \mathrm{~b}$ & $16.53 \pm 0.32 \mathrm{e}$ & $<\mathrm{LOD}$ & $1.05 \pm 0.05 \mathrm{~b}$ \\
\hline $616-26$ & $0.45 \pm 0.04 b c$ & $0.36 \pm 0.02 b c^{*}$ & $99.3 \pm 1.2 \mathrm{de}^{*}$ & $2.36 \pm 0.23 \mathrm{f}$ & $103.9 \pm 1.1 \mathrm{c}-\mathrm{e}^{*}$ & $2.36 \pm 0.05 a-c$ & $4.37 \pm 0.11 \mathrm{~cd}$ & $9.10 \pm 0.43 c$ & $2.91 \pm 0.09 c$ & $1.17 \pm 0.08 \mathrm{bc}$ \\
\hline $616-39$ & $0.37 \pm 0.01 \mathrm{~b}$ & $0.36 \pm 0.02 b^{*} *$ & $95.2 \pm 0.4 \mathrm{~d}$ & $1.93 \pm 0.27 \mathrm{de}^{*}$ & $97.5 \pm 1.5 c$ & $2.14 \pm 0.06 \mathrm{a}-\mathrm{c}$ & $5.04 \pm 0.05 \mathrm{e}$ & $8.70 \pm 0.32 \mathrm{c}$ & $2.83 \pm 0.06 c$ & $1.07 \pm 0.04 \mathrm{~b}$ \\
\hline $616-79$ & $0.09 \pm 0.04 \mathrm{a}$ & $0.24 \pm 0.02 \mathrm{ab}$ & $78.1 \pm 2.5 \mathrm{~b}$ & $1.85 \pm 0.01 \mathrm{de}$ & $82.5 \pm 2.1 \mathrm{~b}$ & $1.85 \pm 0.01 \mathrm{ab}$ & $2.45 \pm 0.02 \mathrm{~b}$ & $4.32 \pm 0.26 \mathrm{ab}$ & $1.95 \pm 0.05 b^{*}$ & $0.73 \pm 0.01 \mathrm{a}$ \\
\hline $616-83$ & $<$ LOQ & $<$ LOQ & $60.2 \pm 0.3 \mathrm{a}$ & $0.47 \pm 0.04 \mathrm{a}$ & $60.9 \pm 1.0 \mathrm{a}$ & $1.73 \pm 0.12 \mathrm{a}$ & $2.43 \pm 0.15 b$ & $2.81 \pm 0.33 \mathrm{a}$ & $1.64 \pm 0.07 a^{*}$ & $0.58 \pm 0.09 \mathrm{a}$ \\
\hline $616-90$ & $0.82 \pm 0.02$ de & $0.82 \pm 0.02 \mathrm{e}-\mathrm{g}$ & $118.3 \pm 0.2 \mathrm{~g}$ & $1.72 \pm 0.01 \mathrm{~d}$ & $128.2 \pm 0.3 \mathrm{~g}$ & $2.48 \pm 0.02 \mathrm{a}-\mathrm{c}$ & $4.16 \pm 0.03 \mathrm{~cd}$ & $13.48 \pm 0.01 \mathrm{~d}$ & $3.81 \pm 0.00 \mathrm{~d}$ & $1.28 \pm 0.01 \mathrm{bc}$ \\
\hline $800-20$ & $0.83 \pm 0.07 \mathrm{f}$ & $0.83 \pm 0.07 \mathrm{~h}$ & $112.8 \pm 1.5 \mathrm{~g}$ & $1.98 \pm 0.05 \mathrm{de}^{*}$ & $118.8 \pm 1.8 \mathrm{fg}$ * & $2.73 \pm 0.06 c$ & $5.78 \pm 0.04 \mathrm{f}$ & $13.25 \pm 0.08 \mathrm{~d}$ & $3.76 \pm 0.02 \mathrm{~d}$ & $1.30 \pm 0.05 \mathrm{bc}$ \\
\hline $800-30$ & $0.53 \pm 0.03 \mathrm{~cd}^{*}$ & $0.53 \pm 0.03 \mathrm{de}^{*}$ & $101.4 \pm 0.4$ ef & $1.88 \pm 0.14 \mathrm{de}^{*}$ & $104.6 \pm 1.8 \mathrm{c}-\mathrm{e}^{*}$ & $2.47 \pm 0.11 \mathrm{a}-\mathrm{c}$ & $9.22 \pm 0.38 \mathrm{~g}$ & $15.14 \pm 0.60 \mathrm{e}$ & $4.14 \pm 0.12 \mathrm{e}$ & $1.70 \pm 0.08 \mathrm{~d}$ \\
\hline $800-40$ & $0.43 \pm 0.01 \mathrm{bc} *$ & $0.43 \pm 0.01 \mathrm{~cd}^{*}$ & $96.5 \pm 0.4 \mathrm{de}^{*}$ & $1.38 \pm 0.08 \mathrm{c}$ & $99.9 \pm 1.7 \mathrm{~cd}^{*}$ & $2.48 \pm 0.11 \mathrm{a}-\mathrm{c}$ & $10.53 \pm 0.38 \mathrm{~h}$ & $16.02 \pm 0.66 \mathrm{e}$ & $4.32 \pm 0.13 \mathrm{e}$ & $1.82 \pm 0.11 \mathrm{~d}$ \\
\hline $800-60$ & $0.15 \pm 0.05 \mathrm{a}$ & $0.15 \pm 0.05 \mathrm{a}$ & $76.4 \pm 0.3 \mathrm{~b}$ & $0.90 \pm 0.04 \mathrm{~b}$ & $74.6 \pm 0.3 \mathrm{~b}$ & $1.82 \pm 0.06 \mathrm{ab}$ & $2.76 \pm 0.01 b$ & $4.85 \pm 0.17 \mathrm{~b}$ & $2.05 \pm 0.03 \mathrm{~b}$ & $0.66 \pm 0.02 \mathrm{a}$ \\
\hline
\end{tabular}

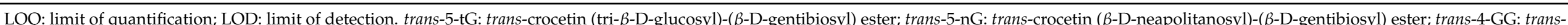

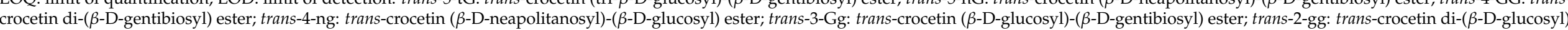

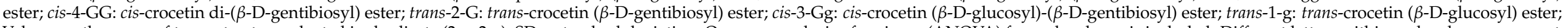

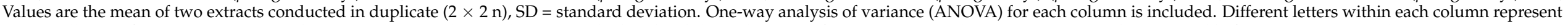
statistically significant variances, according to Duncan test $(p<0.05)$. Data marked with * did not show significant variance with same treatment and compound before storage $(p<0.05)$. 
The two main crocetin esters, trans-4-GG and trans-3-Gg kept the previous proportion, trans-3-Gg concentration being higher than trans-4-GG in all microwave dehydration treatments studied and in the control. The concentration value of trans-4-GG compared to the content obtained before storage decreased slightly in the control, while it increased in some of the microwave dehydration treatments. For trans-3-Gg, the control also obtained lower value compared to its content before storage, and the treatments increased their concentration only in some of them. Regarding trans-4-GG, at $440 \mathrm{~W}$ for $36 \mathrm{~s}, 55 \mathrm{~s}$, and 73 s, along with 616-90 and 800-20, there was significant variance compared to the rest of the treatments. Trans-3-Gg showed similar significant differences to those described for trans-4-GG in relation to the microwave dehydration treatments. As before the storage of the saffron, cis-4-GG and cis-3-Gg were identified and quantified. Regarding cis-4-GG, all microwave treated samples showed significant variances with the control, which obtained the lowest concentration $(1.04 \mathrm{~g} / \mathrm{kg})$. Cis-3-Gg, however, could not be detected in the control and in the treatments performed at $440 \mathrm{~W}$.

Therefore, after storage, new significant variances were observed. Some of the microwave treated samples presented different trends compared to the control. It is noteworthy that microwave dehydrated saffron showed higher total crocetin esters content in some treatments after storage (at $440 \mathrm{~W}$ for $36 \mathrm{~s}, 55 \mathrm{~s}$ and $73 \mathrm{~s}, 616-90$ and at $800 \mathrm{~W}$ for $20 \mathrm{~s}, 40 \mathrm{~s}$ and $60 \mathrm{~s}$ ) and safranal content decreased in 440-73, although the storage is known for improving safranal content but also diminishing carotenoids due to its oxidation $[23,24,40]$. Considering the main metabolites' content of saffron obtained from the different microwave dehydration treatments studied, and compared to the control (traditionally obtained saffron), the treatments that obtained an increase in total crocetin esters after storage also showed high contents of picrocrocin and safranal. These treatments were able to dehydrate stigmas of $C$. sativus L. and obtain saffron with a content of main metabolites equal to or superior to those obtained by traditionally dehydrated saffron. Among them, treatment 800-20 stands out for obtaining saffron with the highest content of picrocrocin, safranal, and total crocetin esters. The 440-130 treatment would stand out for obtaining saffron with a great bioactive capacity. In addition, it would have high content of the main metabolites. On the other hand, 616-83 would not be recommended for use due to the lowest content of all evaluated compounds in the saffron obtained from this treatment.

Discriminant function analysis was performed on results from HPLC-DAD grouped together according to the power used in the dehydration process, in order to identify a relationship between the compounds during the dehydration process and determine canonical functions that separate samples within two functions (Figure 1).

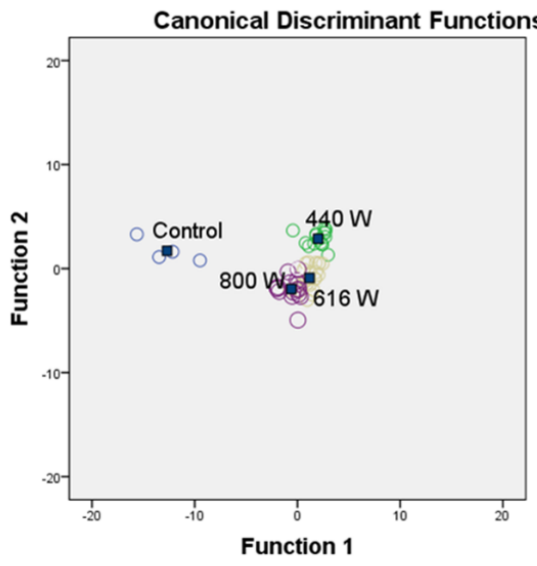

(a)

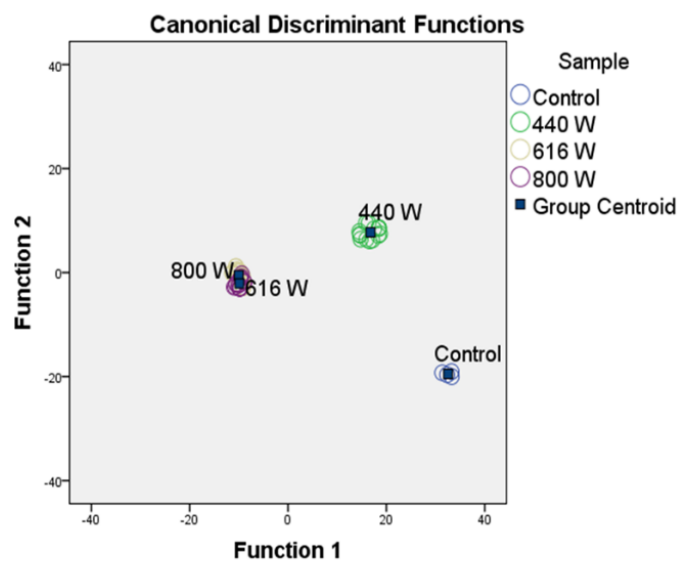

(b)

Figure 1. Graphical plot of the results from the stepwise canonical analysis of saffron samples obtained by microwave dehydration at different powers and control samples, before (a) and after three months of storage $(\mathbf{b})$. 
After the dehydration process, the control sample was separated from microwave dehydrated stigmas by function 1 (71.4\% of variance) and function $2(92.8 \%$ of cumulative variance) (Figure 1a). Function 1 depended on trans-4-GG, trans-3-Gg, and trans-5-nG mainly, and function 2 depended on trans-4-GG, trans-5-tG, and trans-2-G primarily. Similar analysis was performed after three months of storage, and in this case, control sample and stigmas dehydrated at $440 \mathrm{~W}$ were separated from the rest of the treatments by function 1 ( $82.9 \%$ of variance) and function 2 (99.5\% of cumulative variance) (Figure $1 \mathrm{~b})$. In this case, function 1 depended on cis-3-Gg, trans-4-GG, and trans-2-G mainly, and function 2 depended on trans-3-Gg, trans-5-tG, and trans-5-nG, principally. After three months of storage, a higher separation of the treatments at $440 \mathrm{~W}$ due to cis-3-Gg, mainly, was observed. Considering Tables 3 and 5, cis-3-Gg content decreased at $440 \mathrm{~W}$ after storage, while the isomer trans-3-Gg increased. It seems that the dehydration process at this power produces a less stable isomerization than the rest of the powers studied.

Therefore, the microwave dehydration process separated saffron obtained from the stigmas dehydrated by "toasting", and this separation was more pronounced after three months of storage, due mainly to the content of crocetin esters and more specifically to the most abundant crocins.

\subsection{Commercial Quality of Microwave-Dehydrated Saffron}

The commercial quality of saffron is classified into three categories established by ISO 3632 [7]. This standard indicates that the highest quality category must be composed of saffron with a minimum value of 200 of $A_{1}^{1 \%} \mathrm{~cm} 440 \mathrm{~nm}, 70$ of $A_{1}^{1 \%} \mathrm{~cm} 257 \mathrm{~nm}$, and a $A_{1}^{1 \%} \mathrm{~cm}$ $330 \mathrm{~nm}$ value between 20 and 50. Results of UV-vis spectrophotometric analyses of the control and saffron dehydrated at different powers and time lapses are shown in Table 6.

Table 6. UV-vis spectrophotometric parameter values of saffron samples obtained under different microwave dehydration treatments.

\begin{tabular}{|c|c|c|c|c|c|c|c|c|}
\hline \multirow{2}{*}{ Treatment } & \multicolumn{4}{|c|}{$\left(A_{1 \mathrm{~cm}}^{1 \%} \pm \mathrm{SD}\right)$ Initial } & \multicolumn{4}{|c|}{$\left(A_{1 \mathrm{~cm}}^{1 \%} \pm \mathrm{SD}\right)$ after Storage } \\
\hline & $440 \mathrm{~nm}$ & $330 \mathrm{~nm}$ & $257 \mathrm{~nm}$ & Cat. & $440 \mathrm{~nm}$ & $330 \mathrm{~nm}$ & $257 \mathrm{~nm}$ & Cat. \\
\hline Control & $238 \pm 8 \mathrm{ab}$ & $15 \pm 1 \mathrm{a}$ & $146 \pm 24 b$ & - & $235 \pm 12 c$ & $22 \pm 1 \mathrm{ab}$ & $97 \pm 3 \mathrm{e}-\mathrm{h}$ & I \\
\hline $440-36$ & $260 \pm 3 \mathrm{de}$ & $24 \pm 1 \mathrm{~b}-\mathrm{d}$ & $96 \pm 1 \mathrm{a}$ & I & $262 \pm 3$ ef & $26 \pm 1 \mathrm{~b}-\mathrm{e}$ & $97 \pm 1 \mathrm{e}-\mathrm{h}$ & I \\
\hline $440-55$ & $256 \pm 4 \mathrm{~cd}$ & $25 \pm 1 \mathrm{~b}-\mathrm{e}$ & $96 \pm 2 a$ & I & $268 \pm 3 \mathrm{fg}$ & $26 \pm 1 \mathrm{~b}-\mathrm{e}$ & $100 \pm 1 \mathrm{gh}$ & I \\
\hline $440-73$ & $239 \pm 4 \mathrm{ab}$ & $25 \pm 2$ de & $88 \pm 2 a$ & I & $259 \pm 1 \mathrm{~g}$ & $27 \pm 1 \mathrm{c}-\mathrm{e}$ & $95 \pm 1 \mathrm{e}-\mathrm{g}$ & I \\
\hline $440-130$ & $265 \pm 1 d-f$ & $28 \pm 1 \mathrm{f}$ & $99 \pm 1 \mathrm{a}$ & I & $246 \pm 2 c-e$ & $24 \pm 1 \mathrm{bc}$ & $87 \pm 1 c$ & I \\
\hline $616-26$ & $256 \pm 5 \mathrm{~cd}$ & $25 \pm 1 \mathrm{c}-\mathrm{e}$ & $96 \pm 2 a$ & I & $248 \pm 1 \mathrm{c}-\mathrm{e}$ & $19 \pm 1 \mathrm{a}$ & $90 \pm 1 \mathrm{~cd}$ & I \\
\hline $616-39$ & $269 \pm 2$ ef & $25 \pm 2$ de & $100 \pm 1 \mathrm{a}$ & I & $262 \pm 2 \mathrm{ef}$ & $30 \pm 2$ ef & $99 \pm 3 \mathrm{f}-\mathrm{h}$ & I \\
\hline $616-52$ & $274 \pm 3 \mathrm{f}$ & $26 \pm 1$ ef & $102 \pm 1 \mathrm{a}$ & I & $258 \pm 2 \mathrm{~d}-\mathrm{f}$ & $25 \pm 1 \mathrm{~b}-\mathrm{d}$ & $94 \pm 2 \mathrm{~d}-\mathrm{f}$ & I \\
\hline $616-79$ & $259 \pm 1 \mathrm{de}$ & $28 \pm 1 \mathrm{f}$ & $95 \pm 1 \mathrm{a}$ & I & $246 \pm 1 \mathrm{c}-\mathrm{e}$ & $29 \pm 1 \mathrm{de}$ & $93 \pm 2$ de & I \\
\hline $616-83$ & $237 \pm 2 \mathrm{ab}$ & $23 \pm 1 b c$ & $87 \pm 1 \mathrm{a}$ & I & $156 \pm 1 \mathrm{a}$ & $35 \pm 1 \mathrm{~g}$ & $82 \pm 1 b$ & III \\
\hline $616-90$ & $235 \pm 1 \mathrm{a}$ & $26 \pm 1 \mathrm{~d}-\mathrm{f}$ & $89 \pm 1 \mathrm{a}$ & I & $271 \pm 3 \mathrm{fg}$ & $27 \pm 1 \mathrm{c}-\mathrm{e}$ & $97 \pm 1 \mathrm{e}-\mathrm{h}$ & I \\
\hline $800-20$ & $261 \pm 2 \mathrm{de}$ & $26 \pm 2 \mathrm{ef}$ & $101 \pm 1 \mathrm{a}$ & I & $282 \pm 8 \mathrm{~g}$ & $30 \pm 1 \mathrm{c}-\mathrm{e}$ & $110 \pm 4 \mathrm{i}$ & I \\
\hline $800-30$ & $248 \pm 6 b c$ & $25 \pm 1 \mathrm{c}-\mathrm{e}$ & $95 \pm 3 a$ & I & $262 \pm 2 \mathrm{ef}$ & $34 \pm 1 \mathrm{fg}$ & $101 \pm 1 \mathrm{~h}$ & I \\
\hline $800-40$ & $240 \pm 2 \mathrm{ab}$ & $28 \pm 2 \mathrm{f}$ & $98 \pm 6 a$ & I & $243 \pm 3 \mathrm{~cd}$ & $25 \pm 1 \mathrm{~b}-\mathrm{d}$ & $90 \pm 1 \mathrm{~cd}$ & I \\
\hline $800-60$ & $247 \pm 5 \mathrm{a}-\mathrm{c}$ & $23 \pm 1 b$ & $92 \pm 2 \mathrm{a}$ & I & $185 \pm 1 b$ & $25 \pm 1 \mathrm{~b}-\mathrm{d}$ & $76 \pm 1 \mathrm{a}$ & II \\
\hline
\end{tabular}

Mean values of two extracts conducted in duplicate $(2 \times 2 \mathrm{n}), \mathrm{SD}=$ standard deviation. Cat. = Category. A dash in category means it could not be considered as saffron according to ISO 3632 (2011). One-way analysis of variance (ANOVA) for each column is included. Different letters within each column represent statistically significant variances, according to the Duncan test $(p<0.05)$.

The initial results showed that the control could not be classified as saffron according to ISO 3632 [7] due to its low value of $A_{1}^{1 \%} \mathrm{~cm} 330 \mathrm{~nm}$, while all the microwave treatments produced saffron belonging to Category I. Color strength $\left(A_{1}^{1 \%} \mathrm{~cm} 440 \mathrm{~nm}\right)$ results showed that there were several differences across different treatments, although saffron obtained in 440-73, 616-83, 616-90, 800-30, 800-40, and 800-60 did not show significant differences between traditional and microwave dehydration. Values of ISO parameters obtained in mi- 
crowave dehydration treatments are in concordance with those reported by Maghsoodi [5] in a previous essay, taking into account their results obtained at $200 \mathrm{~W}$ for $720 \mathrm{~s}$ (in total), since the same order of energy $(144,000 \mathrm{~J})$ as our work was applied. The values of $A_{1}^{1 \%} \mathrm{~cm}$ $257 \mathrm{~nm}$ were significantly lower for all the microwave dehydration treatments compared to the control.

After storage, the treatments $616-83$ and $800-60$ showed a $A_{1}^{1 \%} \mathrm{~cm} 440 \mathrm{~nm}$ value below 200 , which relegated them to Category III $(\leq 170)$ and II $(\leq 200)$, respectively. These treatments did not maintain the quality previously observed before storage, which shows that they are not suitable for producing high quality saffron.

Saffron value is mainly determined by its $A_{1}^{1 \%} \mathrm{~cm} 440 \mathrm{~nm}$ value, therefore, producers want the saffron with the highest $440 \mathrm{~nm}$ value as possible. Between all the treatments analyzed, those that showed the highest $A_{1}^{1 \%} \mathrm{~cm} 440 \mathrm{~nm}$ value were 440-55, 440-73, 616-90, and 800-20. The last mentioned showed high crocetin esters content in HPLC-DAD analysis, proving to be a good alternative to traditional "toasting" for obtaining high quality saffron.

\section{Conclusions}

We demonstrated that microwave dehydration produces saffron with similar content of crocetin esters and more safranal than saffron obtained from "toasting" under conditions used in 800-20. This treatment maintained high metabolite content after three months of storage; therefore, microwave dehydration provides saffron with high metabolite content and better preservation.

Saffron's commercial quality was measured by UV-vis spectrophotometric analysis in order to classify the saffron obtained into ISO 3632 categories. Between all the treatments that produced saffron belonging to ISO Category I, 800-20 was the one that obtained the highest $A_{1}^{1 \%} \mathrm{~cm} 440 \mathrm{~nm}$ value. The results indicate that saffron obtained from microwave dehydration is an adequate alternative to "toasting" because of the high metabolite content produced and the higher commercial quality obtained.

Author Contributions: Conceptualization, G.L.A. and N.M.-L.; methodology, G.L.A. and N.M.-L.; software, A.G.-B. and N.M.-L.; validation, A.G.-B., N.M.-L., C.L., M.R.S., and G.L.A.; formal analysis, G.L.A. and N.M.-L.; investigation, G.L.A., A.G.-B., and N.M.-L.; resources, G.L.A. and M.R.S.; data curation, G.L.A. and N.M.-L.; writing-original draft preparation, A.G.-B., N.M.-L., C.L., M.R.S., and G.L.A.; writing-review and editing, A.G.-B., N.M.-L., C.L., M.R.S., and G.L.A.; visualization, G.L.A.; supervision, G.L.A.; project administration, G.L.A. and M.R.S. All authors have read and agreed to the published version of the manuscript.

Funding: This research received no external funding.

Institutional Review Board Statement: Not applicable.

Informed Consent Statement: Not applicable.

Acknowledgments: The authors thank the Government of Castilla-La Mancha (Spain) in collaboration with FEDER for the project SBPLY/17/180501/000191.

Conflicts of Interest: The authors declare no conflict of interest.

\section{References}

1. Alonso, G.L.; Zalacain, A.; Carmona, M. Saffron. In Handbook of Herbs and Spices; Elsevier: Amsterdam, The Netherlands, 2012; Volume 1, pp. 469-498. ISBN 9780857095671.

2. Basker, D.; Negbi, M. Uses of saffron. Econ. Bot. 1983, 37, 228-236. [CrossRef]

3. Bagur, M.J.; Alonso-Salinas, G.L.; Jiménez-Monreal, A.M.; Chaouqi, S.; Llorens, S.; Martínez-Tomé, M.; Alonso, G.L. Saffron: An Old Medicinal Plant and a Potential Novel Functional Food. Molecules 2017, 23, 30. [CrossRef]

4. Carmona, M.; Zalacain, A.; Pardo, J.E.; López, E.; Alvarruiz, A.; Alonso, G.L. Influence of Different Drying and Aging Conditions on Saffron Constituents. J. Agric. Food Chem. 2005, 53, 3974-3979. [CrossRef]

5. Maghsoodi, V. Effect of Different Drying Methods on Saffron (Crocus sativus L) Quality. IJCCE 2012, 31, 85-89. [CrossRef]

6. Tong, Y.; Zhu, X.; Yan, Y.; Liu, R.; Gong, F.; Zhang, L.; Hu, J.; Fang, L.; Wang, R.; Wang, P. The influence of different drying methods on constituents and antioxidant activity of saffron from China. Int. J. Anal. Chem. 2015, 2015. [CrossRef] [PubMed] 
7. ISO 3632-1:2011—Spices—Saffron (Crocus sativus L.)—Part 1: Specification. Available online: https://www.iso.org/standard/44 523.html (accessed on 2 February 2021).

8. Carmona, M.; Zalacain, A.; Salinas, M.R.; Alonso, G.L. A New Approach to Saffron Aroma. Crit. Rev. Food Sci. Nutr. 2007, 47, 145-159. [CrossRef] [PubMed]

9. Alonso, G.L.; Salinas, M.R.; Garijo, J.; Sánchez-Fernández, M.A. Composition of crocins and picrocrocin from spanish saffron (Crocus sativus L.). J. Food Qual. 2001, 24, 219-233. [CrossRef]

10. Caballero-Ortega, H.; Pereda-Miranda, R.; Abdullaev, F.I. HPLC quantification of major active components from 11 different saffron (Crocus sativus L.) sources. Food Chem. 2007, 100, 1126-1131. [CrossRef]

11. García-Rodríguez, M.V.; Serrano-Díaz, J.; Tarantilis, P.A.; López-Córcoles, H.; Carmona, M.; Alonso, G.L. Determination of saffron quality by high-performance liquid chromatography. J. Agric. Food Chem. 2014, 62, 8068-8074. [CrossRef]

12. Moratalla-López, N.; Bagur, M.J.; Lorenzo, C.; Martínez-Navarro, M.E.; Salinas, M.R.; Alonso, G.L. Bioactivity and Bioavailability of the Major Metabolites of Crocus sativus L. Flower. Molecules 2019, 24, 2827. [CrossRef]

13. Sarfarazi, M.; Jafari, S.M.; Rajabzadeh, G.; Galanakis, C.M. Evaluation of microwave-assisted extraction technology for separation of bioactive components of saffron (Crocus sativus L.). Ind. Crops Prod. 2020, 145, 111978. [CrossRef]

14. Chen, D.; Xing, B.; Yi, H.; Li, Y.; Zheng, B.; Wang, Y.; Shao, Q. Effects of different drying methods on appearance, microstructure, bioactive compounds and aroma compounds of saffron (Crocus sativus L.). LWT 2020, 120, 108913. [CrossRef]

15. García-Rodríguez, M.V.; López-Córcoles, H.; Alonso, G.L.; Pappas, C.S.; Polissiou, M.G.; Tarantilis, P.A. Comparative evaluation of an ISO 3632 method and an HPLC-DAD method for safranal quantity determination in saffron. Food Chem. 2017, 221, 838-843. [CrossRef]

16. Carmona, M.; Zalacain, A.; Sánchez, A.M.; Novella, J.L.; Alonso, G.L. Crocetin esters, picrocrocin and its related compounds present in Crocus sativus stigmas and Gardenia jasminoides fruits. Tentative identification of seven new compounds by LC-ESI-MS J. Agric. Food Chem. 2006, 54, 973-979. [CrossRef] [PubMed]

17. Sánchez, A.M.; Carmona, M.; Ordoudi, S.A.; Tsimidou, M.Z.; Alonso, G.L. Kinetics of individual crocetin ester degradation in aqueous extracts of saffron (Crocus sativus L.) upon thermal treatment in the dark. J. Agric. Food Chem. 2008, 56, 1627-1637. [CrossRef] [PubMed]

18. Moratalla-López, N.; Bouhadida, N.; Bagur, M.J.; García-Rodríguez, M.V.; Oueslati, S.; Alonso, G.L. Comparing Tunisian and Spanish saffron regarding their bioactive metabolites using HPLC and GC methods. Acta Hortic. 2017, 1184, 279-285. [CrossRef]

19. Jafari, S.-M.; Tsimidou, M.Z.; Rajabi, H.; Kyriakoudi, A. Bioactive ingredients of saffron: Extraction, analysis, applications. In Saffron; Elsevier: Amsterdam, The Netherlands, 2020; pp. 261-290.

20. Carmona, M.; Zalacain, A.; Alonso, G.L. The Chemical Composition of Saffron: Color, Taste and Aroma; Bomarzo SL: Albacete, Spain, 2006; ISBN 9788486977917.

21. Del Campo, C.P.; Carmona, M.; Maggi, L.; Kanakis, C.D.; Anastasaki, E.G.; Tarantilis, P.A.; Polissiou, M.G.; Alonso, G.L. Effects of mild temperature conditions during dehydration procedures on saffron quality parameters. J. Sci. Food Agric. 2010, 90, 719-725. [CrossRef] [PubMed]

22. Bolandi, M.; Shahidi, F.; Sedaghat, N.; Farhoush, R.; Mousavi-Nik, H. Shelf-life Determination of Saffron Stigma: Water Activity and Temperature Studies. World Appl. Sci. J. 2008, 5, 132-136.

23. Carmona, M.; Zalacain, A.; Salinas, M.R.; Alonso, G.L. Generation of Saffron Volatiles by Thermal Carotenoid Degradation. J. Agric. Food Chem. 2006, 54, 6825-6834. [CrossRef]

24. Funebo, T.; Ohlsson, T. Microwave-assisted air dehydration of apple and mushroom. J. Food Eng. 1998, 38, 353-367. [CrossRef]

25. Koocheki, A. Dehydration of saffron stigmas. In Saffron; Elsevier: Amsterdam, The Netherlands, 2020; pp. 291-299. ISBN 9780128186381.

26. Acar, B.; Sadikoglu, H.; Ozkaymak, M. Freeze Drying of Saffron (Crocus sativus L.). Dry. Technol. 2011, 29, 1622-1627. [CrossRef]

27. Crespo, R.J.; Castaño, J.A.; Capurro, J.A. Secado de forraje con el horno microondas: Efecto sobre el analisis de calidad. Agric. Tec. 2007, 67, 210-218. [CrossRef]

28. Soysal, Y. Microwave drying characteristics of parsley. Biosyst. Eng. 2004, 89, 167-173. [CrossRef]

29. De la Hoz, A.; Díaz-Ortiz, Á.; Moreno, A. Microwaves in organic synthesis. Thermal and non-thermal microwave effects. Chem. Soc. Rev. 2005, 34, 164-178. [CrossRef]

30. Galán, A.M.; Calinescu, I.; Trifan, A.; Winkworth-Smith, C.; Calvo-Carrascal, M.; Dodds, C.; Binner, E. New insights into the role of selective and volumetric heating during microwave extraction: Investigation of the extraction of polyphenolic compounds from sea buckthorn leaves using microwave-assisted extraction and conventional solvent extraction. Chem. Eng. Process. Process Intensif. 2017, 116, 29-39. [CrossRef]

31. OJEC Publication of an application for registration pursuant to Article 6(2) of regulation (EEC) No 2081/92 on the protection of geographical indications and designations of origin. Off. J. Eur. Communities. 2000, 6, 4-8.

32. Speranza, G.; Dada, G. 13-cis-crocin: A new crocinoid of saffron. Gazz. Chim. Ital. 1984, 114, 189-192.

33. Llorens, S.; Mancini, A.; Serrano-Díaz, J.; D’Alessandro, A.M.; Nava, E.; Alonso, G.L.; Carmona, M. Effects of Crocetin Esters and Crocetin from Crocus sativus L. on Aortic Contractility in Rat Genetic Hypertension. Molecules 2015, 20, 17570-17584. [CrossRef]

34. Del Campo, C.P.; Carmona, M.; Maggi, L.; Kanakis, C.D.; Anastasaki, E.G.; Tarantilis, P.A.; Polissiou, M.G.; Alonso, G.L. Picrocrocin content and quality categories in different (345) worldwide samples of saffron (Crocus sativus L.). J. Agric. Food Chem. 2010, 58, 1305-1312. [CrossRef] 
35. Chaouqi, S.; Moratalla-López, N.; Lage, M.; Lorenzo, C.; Alonso, G.L.; Guedira, T. Effect of drying and storage process on Moroccan saffron quality. Food Biosci. 2018, 22, 146-153. [CrossRef]

36. Moratalla-López, N.; Parizad, S.; Habibi, M.K.; Winter, S.; Kalantari, S.; Bera, S.; Lorenzo, C.; García-Rodríguez, M.V.; Dizadji, A.; Alonso, G.L. Impact of two different dehydration methods on saffron quality, concerning the prevalence of Saffron latent virus (SaLV) in Iran. Food Chem. 2021, 337. [CrossRef] [PubMed]

37. Parizad, S.; Dizadji, A.; Habibi, M.K.; Winter, S.; Kalantari, S.; Movi, S.; Lorenzo, C.; Alonso, G.L.; Moratalla-López, N. The effects of geographical origin and virus infection on the saffron (Crocus sativus L.) quality. Food Chem. 2019, 295, 387-394. [CrossRef] [PubMed]

38. Maggi, L.; Carmona, M.; Zalacain, A.; Kanakis, C.D.; Anastasaki, E.G.; Tarantilis, P.A.; Polissiou, M.G.; Alonso, G.L. Changes in saffron volatile profile according to its storage time. Food Res. Int. 2010, 43, 1329-1334. [CrossRef]

39. Sereshti, H.; Ataolahi, S.; Aliakbarzadeh, G.; Zarre, S.; Poursorkh, Z. Evaluation of storage time effect on saffron chemical profile using gas chromatography and spectrophotometry techniques coupled with chemometrics. J. Food Sci. Technol. 2018, 55, 1350-1359. [CrossRef]

40. Raina, B.L.; Agarwal, S.G.; Bhatia, A.K.; Gaur, G.S. Changes in pigments and volatiles of saffron (Crocus sativus L) during processing and storage. J. Sci. Food Agric. 1996, 71, 27-32. [CrossRef] 